\title{
THE AFFECTING FACTORS OF MAIZ FARMING PRODUCTION IN RARAMPADENDE VILLAGE WEST DOLO DISTRICT
}

\author{
Ellyani $^{(1)}$, Made Antara ${ }^{()}$, Lien Damayanti ${ }^{l)}$ \\ ${ }^{1)}$ Department of Agriculture and Food Crops. Central Sulawesi Province. \\ ${ }^{2)}$ Lecturer and Researcher at Department of Agribusiness Faculty of Agriculture. University of Tadulako. Palu.
}

\begin{abstract}
This study aims to determine the influence factors of land production, fertilizer, labor, seed and Dummy (seeds) as well as the agricultural extension to the production of maize in the village of Rarampadende, west Dolo District. The population in this study is the farmers who became members of farmers who run the farm corn amounted to 120 people, the number of samples is as many as 52 people, while the data were analyzed using multiple linear analysis of Cobb-Douglass. Results of the analysis showed that the production of the independent variables (Xi) together can have a significant effect on the dependent variable (Y). F-count value is equal to 27.103> F-table 2.44 (Significantly, $0,000 \propto 5 \%$ ), in addition to the value of the coefficient of determination (R2 adjsSq) of 0.754 means that $75.40 \%$ of the variation in maize production (Y) can be explained by variable land area (X1), the number of seeds (X2) labor (X3), the amount of fertilizer (X4), seeds (D1) and agricultural extension (D2), while $24.6 \%$ can be explained other models. Land use, fertilizer, labor, seed, seeds and labor will simultaneously be able to affect the production of maize farming in Rarampadende village, West Dolo district.
\end{abstract}

Key Words : Maize farming, production factors and production.

\section{INTRODUCTION}

Maize is one of the main commodity crops in Indonesia. Aside from being a staple food, maize can also be processed into a variety of food industry products, including syrup, vegetable oil, various snacks, maize and margarine. Various attempts have been made in order to increase maize production, either through intensification or through extension program. In 2014 maize production in Central Sulawesi province reached 169788 tones with crop land area 41573 ha with productivity reached $50.00 \mathrm{kw} / \mathrm{ha}$.

Sigi District has a number of corn production of 48.372 tons. The total area harvested and area high production, but not with the amount of productivity. West Dolo Subdistrict is one of corn producing areas in Sigi regency with harvest area in the amount of 12062 ha and productivity reached 4.24 tons/ha. Rarampadende village is a maize production areas and also one of the main areas for the development of the corn industry which were considered potential enough, the amount of corn production in the village of Rarampadende in 2014 reached 1,639 tones with a productivity of 6.16 tones/ha.

Corn farming is done intensively by farmers aiming to get maximum results. However, there are still many constraints faced by farmers. These problems include: the narrowness of the land owned by farmers, season climatic conditions (drought) which inhibit the productivity of the agriculture, the limited use of technology, and the low quality of human resources of the farmers. Another factor that is often experienced by the most corn farmers is lack of the capital to buy inputs such as seed, fertilizer and agricultural medicines. (Sincere, 2003). 
The achievement of the desired objectives in the agricultural sector can't be separated from the progress of human resources. Agricultural extension is one solution to solve the problems faced by farmers in recent years, it is an effort to improve the work competency of the human resources of the farmers, some of the recommended solution is: change the mindset and behavior of farmers who tend to be more oriented aspects production alone, weak institutional organization of farmers, still weak farmers' access to capital, technology, production facilities and market information, as well as the low quality of human resources working in the agricultural sector.

Based on the research results, the achievement of production and productivity still not in accordance with what is aspired. This is caused by the use of production inputs which are still not optimal which impacted the productivity of the production, the maize potential production is not in accordance. These conditions encourage the researchers to conduct analysis research on the production factors that influence the increase on the production of corn farming that had been undertaken by acorn farmer in Rarampadende village West Dolo District, Sigi. The final results of this study are expected to be used as reference material as well as the information for maize farming development of in the future.

\section{METHODS}

This research was conducted in the village of Rarampadende, District West Dolo, Sigi. The location determination is done intentionally (purposive), with the consideration that Rarampadende Village is one of the villages in the district of corn production centers Dolo West. The research was conducted in November 2015 occurred until January 2016.

Sample selection is done randomly (simple random sampling), the number of samples Determinate by using the Slovin formula, so that the number of samples used in this study is as much as 52 farmers by the total of the population 120 people. (Sevila et.al, in Kurniasar, 2011):

$$
n=\frac{N}{1+N e^{2}}
$$

Description:

$\mathrm{n}=$ Number of Samples.

$\mathrm{N}=$ Number of population.

Data Analysis Methods. The method of analysis of research data using multiple linear regression with Cobb-Douglas production function.

$\mathrm{Ln} Y=\ln \mathrm{b} 0+\mathrm{b} 1 \ln \mathrm{X} 1+\mathrm{b} 2 \ln \mathrm{X} 2+\mathrm{b} 3 \ln$

$$
\mathrm{x} 3+\mathrm{b} 4 \ln \mathrm{X} 4+\mathrm{D} 1+\mathrm{D}_{2}+\mathrm{u}
$$

Transform to natural logarithm:

$$
\mathrm{Y}=\mathrm{boX} \mathrm{X}_{1}^{\mathrm{b} 1} \cdot \mathrm{X}_{2}^{\mathrm{b} 2} \cdot \mathrm{X}_{3}^{\mathrm{b} 3} \cdot \mathrm{X}_{4}^{\mathrm{b} 4} \cdot \mathrm{D}_{1} \cdot \mathrm{D}_{2} \cdot \mathrm{e}^{\mathrm{\mu}}
$$

Description:

$\mathrm{Y}=$ Maize Production $(\mathrm{Kg})$

$\mathrm{X}_{1} \quad=$ Land $(\mathrm{Ha})$

$\mathrm{X}_{2}=$ Total Fertilizer $(\mathrm{Kg})$

$\mathrm{X}_{3} \quad=$ Number of Seeds $(\mathrm{Kg})$

$\mathrm{X}_{4} \quad=$ Number of Workers $(\mathrm{Kg})$

$\mathrm{D}_{1} \quad=$ Dummy Varieties Seed $\left(\mathrm{D}_{1}=1\right.$, yielding seeds; $\mathrm{D}_{1}=0$, local seed)

$\mathrm{D}_{2}=$ Dummy Characteristics Extension $\left(\mathrm{D}_{2}=1\right.$, active; $\mathrm{D}_{2}=0$, inactive $)$

$\mathrm{b}_{\mathrm{o}} \quad=$ Intercept

$b_{1}-b_{4}=$ Regression Coefficient

$\delta_{1}-\delta_{2}=$ Coefficient Of Dummy

$\mathrm{e} \mu \quad=$ Error Disruptors $($ Error Term)

The Suitability of the multiple regression model can be tested by using several indicators, namely:

a) the coefficient of determination (R2): used to determine how much the dependent variable (Y) can be explained by the independent variable (X), with the following formula:

$$
\mathrm{R}^{2}=\frac{\text { Amount of Quadratic Regression }}{\text { Amount of Quadratic Total }}
$$

b) Test Simultaneous (Test-F), to determine the influence of the independent variables simultaneously against the dependent variable, $F$ test-with the following formula: (Gujarati, 1995). 


$$
\mathrm{F}=\frac{\mathrm{KTR}}{\mathrm{KTS}}
$$

Description:

$\mathrm{F} \quad=$ Fisher's exact test (Fisher test)

KTR = Central Squares Regression

KTS = Central Time squares

Statistical Shape:

1. $\mathrm{H}_{0 \text { : }}$ bi $=0$, means that the factors that observed has no significant influence effect on production.

2. $\mathrm{H}_{1}$ : at least one bi $\neq 0$, means that the production factor observed significantly affect the production.

Under the condition :

1. If F count $\leq \mathrm{F}$ tables, then Ho accepted means jointly independent variable (X) has no real effect on the dependent variable (Y) at the confidence level $\alpha$.

2. If $F$ count $>F$ table then Ho is rejected, means that together with the independent variable $(\mathrm{X})$ has significant effect on the dependent variable $(\mathrm{Y})$ at the confidence level $\alpha$.

c) Individual Test (Test-t), to determine the influence of the independent variable (X) on the dependent variable (Y) partially used $t$ test ( $\mathrm{t}$ test) with the following formula: (Gujarati 1995)

$$
t \text { hitung }=\frac{\mathrm{b}_{\mathrm{i}}}{\text { St. } \mathrm{b}_{\mathrm{i}}}
$$

Description:

$$
\begin{array}{ll}
\mathrm{t} & =\mathrm{t} \text { test } \\
\mathrm{b}_{\mathrm{i}} & =\text { coefficient of variable } \mathrm{i}-\mathrm{th} \\
\mathrm{Sb}_{\mathrm{i}} & =\text { Standard error variable } \mathrm{i}-\mathrm{th}
\end{array}
$$

Form a hypothesis:

1. $\mathrm{H}_{0} \mathrm{~b}_{\mathrm{i}}=0$ allegedly independent variable has no significant effect on the dependent variable.

2. $\mathrm{H}_{1} \mathrm{~b}_{\mathrm{i}} \neq 0$ allegedly independent variable has significant effect on the dependent variable.

Under the condition :

a. If $t$ count $\leq t$ table, then Ho is accepted it means partially independent variable (X) has no real effect on the dependent variable $(\mathrm{Y})$ at the confidence level $\alpha$.

b. If $\mathrm{t}$ count $>\mathrm{t}$ table, then Ho is rejected, means that partially independent variable
(X) has significant effect on the dependent variable (Y) at the confidence level $\alpha$.

d) Classical Assumption Examination

1. Multicollinearity Test: performed by observing the value of Pearson correlation matrices. Guidelines for a regression model of non multikollinearty performed by observing the correlation matrix. If in the correlation matrix less than 0.8 it can be concluded that between independent variables does not happen multikollinearity. (Gujarati, 1995).

2. Autocorrelation Test: was conducted to test whether in a linear regression model there is a correlation between disturber error in period $\mathrm{t}$ with disturber error in period $\mathrm{t}-1$ (previous). If there is a correlation, it is called autocorrelation. Sulaiman (2002), presence or absence examination of the correlation between independent variables (autocorrelation) was performed using the Durbin-Watson statistic test with the following criteria:

1) $1.65<\mathrm{DW}<2.35$, which means no autocorrelation.

2) $1.21<\mathrm{DW}<1,65$ or $2.35<\mathrm{DW}<2.79$ meanscan not be inferred.

3) $\mathrm{DW}<1.21$ or DW> 2.79, which means autocorrelation.

3. Heteroskidastisity: performed by observing at the pattern of dots on scatterplot graph. Priyatno (2009), suggests the criteria on which the decision is as follows:

1) If there is a specific pattern, such as dots exist that form a particular pattern of regular (wavy, widened, then narrowed) then Heteroskidastity.

2) If there is no clear pattern, such as the dots spread above and below the number of 0 on the $\mathrm{Y}$ axis, then there is no Heteroskidastity.

\section{RESULTS AND DISCUSSION}

\section{Results}

Respondent Characteristics. Through the results of observations and interviews obtained by the internal characteristics of 
the farmer respondents including age, education level, experience in farming, and the number of dependents in the family. Age level of the respondents are quite diverse, where the youngest is 18 years old and the oldest was 66 years of age. Classification of the age of the respondents is presented in Figure 1.

The education level of the respondents corn farmers in the village of Rarampadende obtained information that the highest level of formal education achieved are Junior High School
(SMP). For more details can be seen in Figure 2.

The number of dependents in the family of the respondent corn farmers in the villageof Rarampadende, known is an average of 4 For more details can be seen in Figure 3.

The range of farm capital owned by the corn farmer respondents ranged from Rp 200,000 to $\operatorname{Rp~1,750,000~every~process~}$ of production and distribution. The range of farming capital of the respondents can be seen in Figure 4.

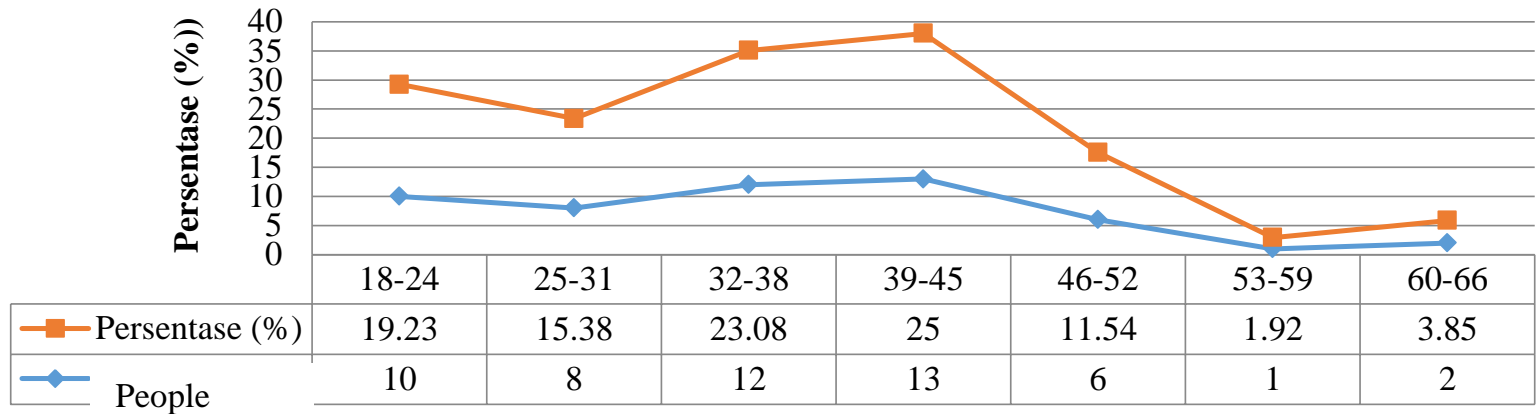

Source: Primary Data 2016.

Figure 1. Respondent's Age Classification

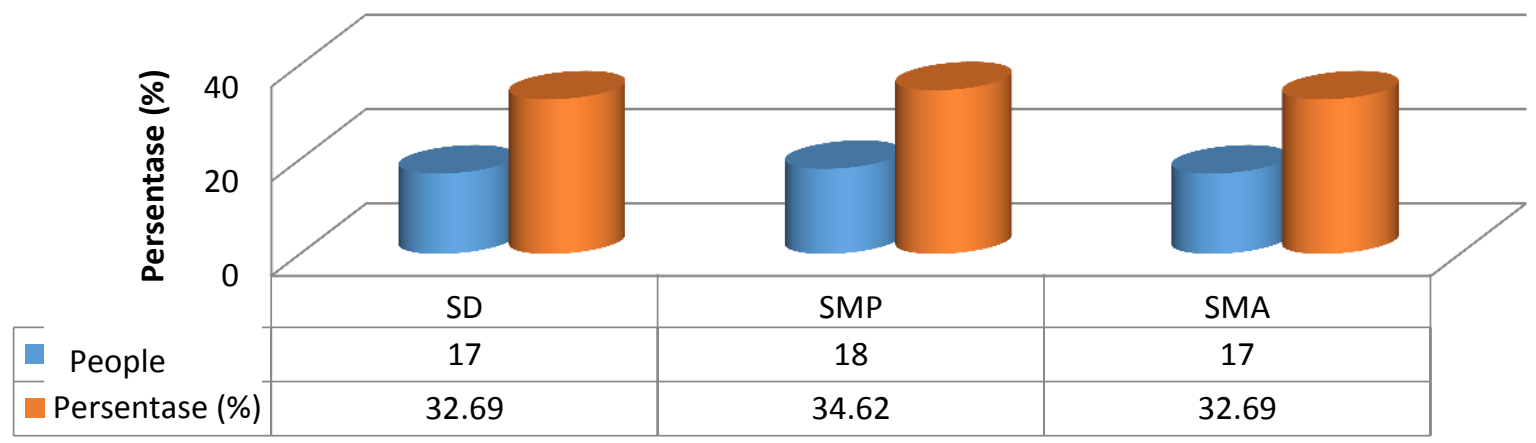

Source: Primary Data in 2016.

Figure 2. Respondent Education Level Classification

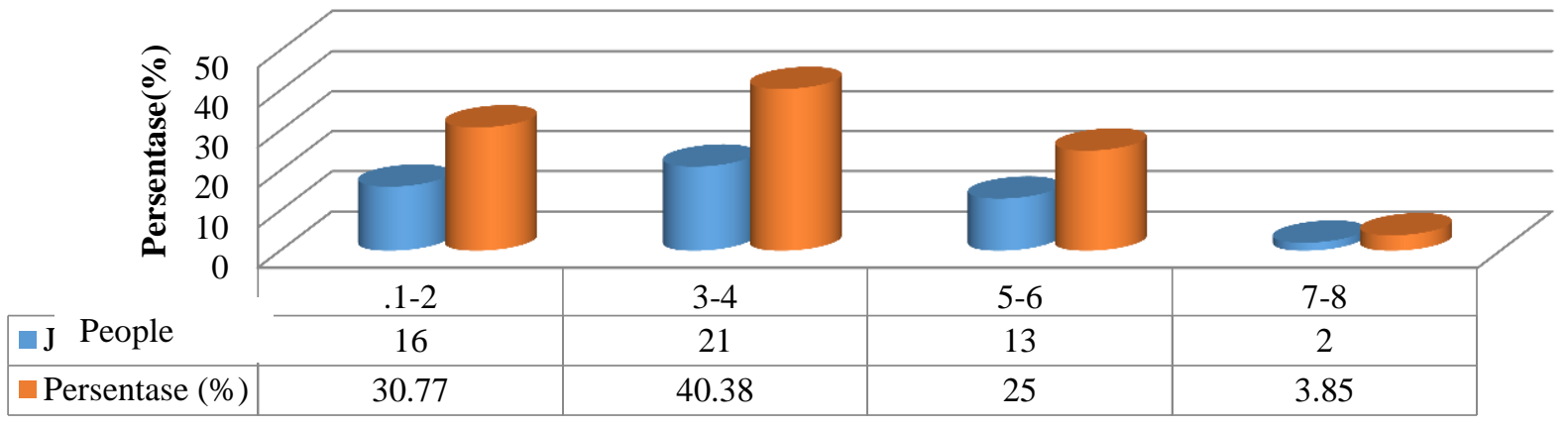

Source: Primary Data 2016.

Figure 3. The Number of Dependents Family Corn Growers 


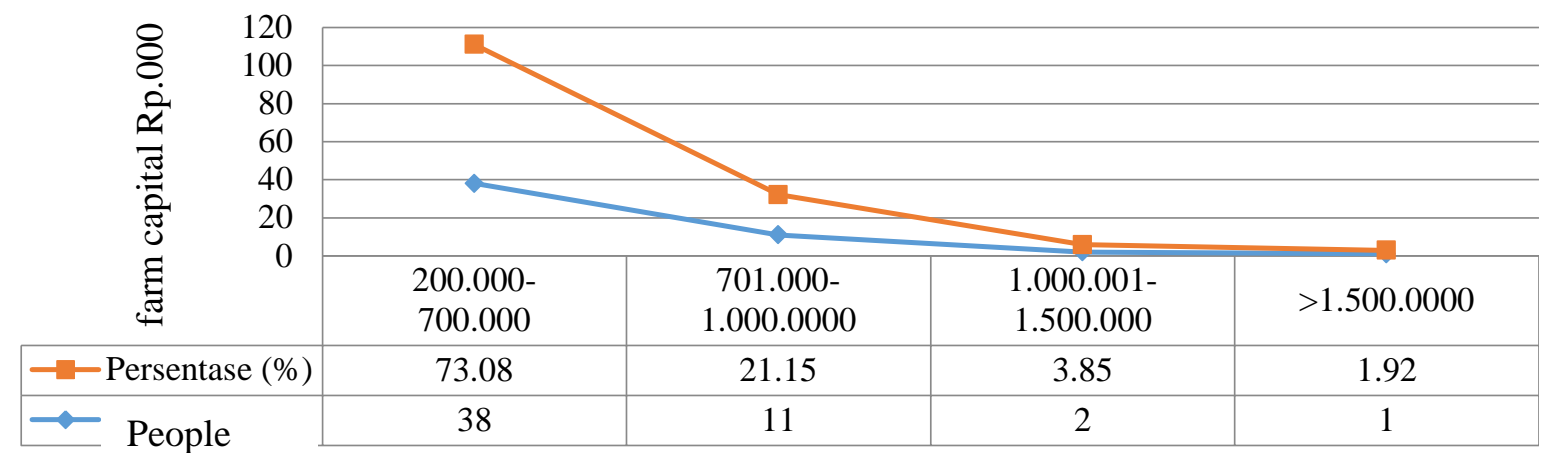

Source: Primary Data, 2016

Figure 4. The Number of Dependents Family Corn Growers

Classical Assumption Test.

Multicolinearity Test. The independent variables based on the VIF and the value of tolerance. Multicolinearity symptoms can be seen from the Variable Inflation Factor (VIF) (Webster, 1998). In Riyadi (2007) if the figure VIF none exceeds 10 or the value of tolerance is less than 0.1 , it can be said to have occurred multicolinearity. Based on this also can be seen that all the independent variables in the models proposed are free of multicolinearityor no multicolinearity among the independent variables in the model. This is indicated by VIF under the number 10 , and the values of tolerance $>0.10$, so it can be concluded that the model equations do not contain multicolinearity.

Heteroskidastity Test. Conducted on a model that uses independent variables (eg, land area, number of seeds, number of employees, amount of fertilizer, seeds and agricultural extension) is done through a method chart which shows the absence of certain patterns that are formed as corrugated, widened later narrows and points spread above and below the number 0 (zero) on the $\mathrm{Y}$ axis, it can show that there are no symptoms Heteroskidastity on the model. Gujarati (2003) in Riyadi (2007) argued that a good regression model must meet the Homoskedastisity assumptions, Homo means the same while scedasticity means the spread, which is among the same variance.
Autocorrelation Symptoms Test. Existing in regression models showed that the regression model with independent variables were performed through the detection value of Durbin Watson (DW) showed the value DW Statistics $=1.338$, Number of data 52, and the number of independent variables $(\mathrm{k}=6)$, and the value DW table $\alpha=5 \%, \mathrm{dL}=1.310$ and $\mathrm{dU}$ $=1.815$. Value $4-\mathrm{du}$, with $\alpha=5 \%=4$ to $1.815=2,185$, and the value of $4-\mathrm{dL}=$ $4-1310=2.690$. Based on the test results of the D-W can also be concluded that the function of the shape of the empirical models used can be detected linear or not, because the value of $\mathrm{d}$ DW lies between $\mathrm{dL}$ (1.310) <DW (1.338) < dU (1,815).

Production Input Analysis. Through the results of linear regression analysis obtained by the value of the coefficient of determination (R2Adj-sq) that is equal to 0.754 , indicating the range or variation of the rise and fall of the independent variable (independent) (Xi) in the form of land area, the amount of seed, fertilizer, labor, dummy seeds and dummy extension of $75.40 \%$ which simultaneously have affected the magnitude of the amount of corn production (dependent) $(\mathrm{Y})$ in the village of Rarampadende, west Dolo district while the remaining $24.60 \%$ influenced by other factors outside the model.

Through the $\mathrm{F}$ test results known that the F-count value is equal to 27.103 (sig.0,000) which is greater than the value of the F-table ( $\mathrm{p}$ value> 0.05) so 
that simultaneously, the use of factors of production (including land area, number of seeds, labor, the amount of fertilizer, dummy type of seed and the dummy Extension) tested had a noticeable effect until the level of $95 \%$ of the production of corn in the village of Rarampadende, West Dolo district, so Ho refused and H1 accepted, this means the number of results corn production is influenced by the factors of production (land area, number of seeds, labor, the amount of fertilizer, seeds and extension).

Based on the analysis in Table 1. known that the independent variables which covers land area (X1), Total Seed (X2), Labor (X3), Total Fertilizer (X4), Seed Varieties (D1) and extension (D2) was highly significant at the $95 \%$ confidence level. Estimates of the multiple regression equation Cobb-Douglass by transforming the data into the natural logarithm (ln) to form the formula is as follows :

$\ln \mathrm{Y}=6.397+0.193 \ln \mathrm{x}_{1}+0.162 \ln \mathrm{X}_{2}-0,078$ $\ln \mathrm{X}_{3}+0,218 \quad \ln \mathrm{X}_{4}+0,171 \quad \ln \mathrm{D}_{1}+$ $0,114 \ln \mathrm{D}_{2}+\varepsilon$

$\mathrm{Y}=(10)^{6.397 .} \mathrm{X}_{1}{ }^{0,193} \cdot \mathrm{X}_{2}{ }^{0.162} \mathrm{X}_{3}{ }^{-0.078} \mathrm{X}_{4}{ }^{0.218}$
$\mathrm{D}_{1}{ }^{0.171} \mathrm{D}_{2}{ }^{0.114}$ $\mathrm{Y}=600.04 \cdot \mathrm{X}_{1}^{0,193} \cdot \mathrm{X}_{2}^{0.162} \mathrm{X}_{3}^{-0.078} \mathrm{X}_{4}^{0.218}$ $\mathrm{D}_{1}^{0.171} \mathrm{D}_{2}^{0.114}$

The coefficient of the intercept (b0) of farm production function equation 6.397 Corn with exponential coefficient intercept so it becomes 600.04. This means that if the use of the production inputs have not improved at all or equal to zero, then the corn production in Rarampadende village, District West Dolo amounted to $600.04 \mathrm{~kg}$.

The value of the regression/ elasticity coefficient (b1-b4, D1-D2) when summed turns of to be 0.780 , less than 1 $(0.780<1)$, this means that the farming of maize in the village of Rarampadende west Dolo distric, in the Return to Scale (RTS) assessed tend to be in decreasing return to scale. This condition states that there is no increasing number of production through the addition of corn in the research sites despite the use of production inputs (such as land, seed number, the amount of fertilizer, labor and dummy variables (species/varieties of seeds and agricultural extension).

\section{The Discussion of The Production Inputs Influence. \\ Production Factor-land Area (X1). The} results of the analysis of the land area (X1) has significant effect in a positive (positive highly significant) against the amount of corn production (Y) at the level of $95 \%$. This can be seen from the value $t$ count the amount of (3.479) significant $(0.001)$, where the $p$ value was $>0.05$ so that Ho refused and $\mathrm{H} 1$ accepted. The value of elasticity (b1) land area (X1) of 0.193 indicates that the addition of inputs of the land area of $1 \%$ can provide additional on the number of corn production amounted to $0.193 \%$ on the assumption that other production factors held constant (citeris paribus).

Land is one of the determinants of the high or low number of resulting production. The larger the area of the land under cultivation, the greater the opportunity to produce the amount of production. Through observations and interviews with the responded farmers, it is known that the average area of the maize farmland area is 0.74 hawith the number of production performance as much as $2,331 \mathrm{~kg} / \mathrm{ha}$ dry seed 0.72 or as much as 3,148 kg/ha. Mudakir (2011) suggested that one of the factors that have a level of productivity is arable land. The condition cause certain areas of agricultural businesses that have limited land area has a low of production or income earned, it can be said that the vast amount of land or land have a positive influence on the production.

Total Seed Production Factor (X2). Results shown from the analysis of the number of seeds (X2) was significantly positively to 
the result of the amount of corn production (Y) at the level of $95 \%$, with the value of $t$ count (2.881)> t-table (2.010), so that Ho refused and $\mathrm{H} 1$ accepted. The elasticity or regression coefficient (b2) of the number of seeds (X2) is approximately 0.162 indicating that the addition of seeds at $1 \%$ can increase the amount of corn production that is equal to $0.162 \%$ by assuming that other production factors should be considered constant (citerisparibus). According to the results of observations and interviews to farmers of corn, the average use of seeds by farmers respondents is 9.5 $\mathrm{kg} / \mathrm{ha}$ or 0.74 at $12.88 \mathrm{~kg} / \mathrm{ha}$ achievement production number $2,331 \mathrm{~kg} / 0.74$ ha (3.148 tons/ ha).

The role of the seed is very important in agriculture, the availability of seed every time when they are needed allows farmers to be planted in a timely manner. Sadjad (1997) in Khaerizal. H (2008) suggests that seed, is a factor of production inputs are included in the component management or management in four internal factors that affect the outcome of the production. Seeds and other production inputs are also managed by the farmers so that they can produce the production output in accordance with what is expected. Selection factors and also the use of the seed becomes very important, it is because the seed is one of the critical factors for success in an agricultural production activity. Kuswanto (1994) in Baswarsiati (2005) suggested that an appropriate and effective compositions is needed in the use of seeds in each area of land cultivated so that the achievement of optimal production can be obtained.

Production Factor-Labor (X3). The results of multiple regression analysis by Cobb Douglass in the use labor (X3) hasw significantly negative effect towards the increased of corn production (Y) at the $95 \%$ confidence level, with a value of t-count $(-2.421)>$ t-table (2.010), so Ho rejected and $\mathrm{H}_{1}$ accepted. The value of the elasticity or regression coefficient (b3) of the labor
(X3) of -0.078 indicates that the addition of labor inputs by $1 \%$ can reduce the production of maize amounted to $0.078 \%$ by assuming other production factors held constant (ceterisparibus).This means that the use of labor need to be reduced to obtain higher production. Average employment in one process of production by farmers as respondents is $19,90 . \mathrm{HOK} / 0.74$ ha or $26.88 \mathrm{HOK} / \mathrm{ha}$.

The use of labor is a factor that must be met for the survival of farming activities corn, ranging from land management to harvest time. The use of labor would have to be carefully and thoroughly considered. Excessive use of labor will certainly increase the cost of production otherwise earned income will be reduced, it even can potentially incur losses.

In the economic theory explained that the additional amount of labor can only be done up to a certain point. Increasing the number of workers that are not controlled or exceeds in a certain point can reduce the production levels. This is explained by the increase of the law of diminishing returns. This law states that the increase in the number of labor should only be conducted until the marginal physical product of labor is equal to zero. When the marginal physical product of labor is equal to zero, the increasing number of labor will lead marginal physical product of labor in to negative. (Ola and Andreas Soekamto, 2013).

\section{Production Factor-Fertilizers Quantity} (X4). Based on the analysis, the amount of fertilizer (X3) highly significantly positive to the increase of corn production $(\mathrm{Y})$ at the level of $95 \%$, with a t-count value equal to ( 3.647) > t-table (2.010), so Ho rejected and $\mathrm{H}_{1}$ accepted. The elasticity or regression coefficient (b4) the amount of fertilizer (X4) of 0.218 indicates that the addition of production inputs by $1 \%$ the amount of fertilizer can increase corn production by $0.218 \%$ with the assumption that other production factors held constant (ceterisparibus). Based on the Observations 
and interviews with corn farmers discovered that the average use of fertilizers by farmers of respondents was $138 \mathrm{~kg} / 0.74$ ha or 186 $\mathrm{kg} / \mathrm{ha}$ obtained by the average amount of corn production $2.331 \mathrm{~kg} / 0.74$ ha or 3,148 $\mathrm{kg} / \mathrm{ha}$. The type of fertilizer used are Urea and SP-36.

Fertilizer is one of the important aspects in the cultivation of plants that provide a direct influence on the growth and quality of production of the crop in terms of the availability of nutrients in the soil. The composition of the fertilizer to get the efficiency of fertilizer required by each crop is influenced by: type, quantity, time and route of administration of fertilizers. Rukmana (2008) argued that through the balance of the appropriate dose of fertilizer, can be obtained a high amount of production of each crop area, in addition, the expenses of production factors can also be suppressed.

Suwalan et al., (2004) in the Sahara et al. (2006) suggests that the response of plants against fertilizer would increase if the fertilizer type, dose, time and method being used is proper. Prasetyo (1982) in Fitriawati, (2009) suggested that in order to achieve high quality and good production levels the farmer should apply different types of fertilizers in sufficient doses, impartial and correct fertilization process.

Agricultural Extension and Dummy Varieties of Maize. The results of multiple regression analysis of Cobb Douglass in the use of corn seed varieties (D1) which was highly significant (significant) positively to the increase of the production of maize (Y) at the $95 \%$ confidence level, with a $\mathrm{t}$-count value of (2.814)> t-table was (2.010), so that Ho refused and $\mathrm{H} 1$ accepted. The value of the elasticity/regression coefficients (d1) of maize seed varieties (D1) of 0.171 indicates that the use of corn seed varieties by $1 \%$ can increase the yield of corn production amounted to $0.171 \%$ by assuming other production factors held constant (ceteris paribus). Results of studies have shown that the increased use of composite superior maize varieties will have a positive influence on the increase in the amount of production of corn in Rarampadende village, West Dolo District. The use of superior composite maize varieties needs to be done in order to increasing the results that will be obtained. Number of farmers respondents who use superior maize varieties (composite) are as many as 27 people (51.92\%) with the amount of corn production performance average of $2579 \mathrm{~kg} / \mathrm{ha}$, whereas the respondent farmers who use local corn seed varieties are as many as 25 people $(48.08 \%)$ with the amount of corn production performance obtained is as much as $1,687 \mathrm{~kg} / \mathrm{ha}$.

An increase of production in agriculture can not be separated from the availability of quality seed. The lack of use of quality seed by farmers due to the lack of understanding of the farmers of the benefits of quality seeds, farmers tend to make their own seeds without considering the quality it has. Sutopo (2003) argued that farmers often suffered losses are not small, both in terms of the costs used, and the loss of valuable time, as a result of the use of poor seed quality. Rachman et al., (2000), suggests that the use of varieties continuously from season to season in an overlay it will decline the production results.

Suparyono and Setyono (1993) suggests that the quality of the seed determines the success of a farm, so that when the ability of lower growth, the number of population per unit area will also be reduced. Further stated that based on quality, seed planted must be on high quality with the provisions of: (1) Have viability or be able to sustain its growth and be a good quality plant, and (2) It has a purity, means it doesn't contaminate by the dirt of other seedlings, free pests and diseases.

The results of multiple regression analysis of Cobb Douglass in variable agricultural extension, in terms of the liveliness of agricultural extension workers 
in fostering to farmers or th corn farmer groups was highly significant, positively to the increase in corn production $(\mathrm{Y})$ at the $95 \%$ confidence level, with a value of $\mathrm{t}$-count equal to (2.162)> t-table (2.010), so that $\mathrm{Ho}$ refused and $\mathrm{H} 1$ accepted. The elasticity or regression coefficient $(\delta 2)$ of agricultural extension (D2) is equal to 0.114 and the agricultural extension activity level by $1 \%$, can increase the amount of corn production amounted to $0.114 \%$ on the assumption that other production factors held constant (ceteris paribus). The results of this study indicate that the improvement of education by increasing the activity of the agricultural extension workers in the field will have a positive influence on the increase of the amount of corn production in Rarampadende village, thus an increase in the activity of agricultural extension is necessary to do in order to obtain an advance result. The number of farmers of respondents who believe that the extension are active is as much as 29 people (55.77\%), while the farmer respondents who found that the trainers are less active are as many as 23 people $(44.23 \%)$.

Agricultural extension workers are required to be able to convey the message that is innovative that is able to change or even encourage a change, in order to realize the improvement of the quality of life of each individual and even the whole society (Mardikanto, 1993). Messages or extension materials submitted must be in accordance with the needs of the farmers, should be based on the opportunity, the willingness and ability of the farmers to implement it, not because of the scientific calculations that considered beneficial.

The attitude of the farmer respondents against the changes describe the acceptance or the openness of the farmers in accessing technology. Farmers who have an open attitude towards the changes will be easy to interact with the agricultural extension workers. Rogers and Shoemaker (1971) in Indraningsih (2011), suggest that individuals which are oriented to the transformation will always renew itself, open to new things and is active in seeking information.

\section{CONCLUSIONS AND RECOMMENDATION}

\section{Conclusions.}

Factors of production such as land area, number of seeds, labor, the amount of fertilizer, seeds dummy factor (varieties) and agricultural extension workers provide a significant influence on the amount of corn production in the village Rarampadende, District West Dolo. Similarly, the (simultaneous) factors: land area, number of seeds, number of employees, amount of fertilizer, seeds (varieties) and agricultural extension, which is also very significantly has effect on the increase of corn production.

Statistical test results obtained against the adjusted regression coefficient is R-adj. square ( $R 2)$ 0754. The influence of the independent variables (land area, number of seeds, labor, the amount of fertilizer, seed varieties and the dummy agricultural extension, simultaneously has significant effect on the production of corn in Rarampadende village with the value of F-count (27.103)> F-table (2.034) at the level of $\alpha$ at $5 \%$ (Significant two tile).

$\mathrm{T}$ test results in partial land area, number of seeds, number of employees, amount of fertilizer, Dummy (seeds/varieties and agricultural extension) influence significantly $(0,000)$ at the level of $\alpha=5 \%$ to the increase of corn production in Rarampadende village, West Dolo sub district.

The function of the maize farming in the research area is on the condition of Return to Scale (RTS) amounted to $0.780<$ 1 tend to decline (decreasing increasing returns to scale).

\section{Recommendation.}

The corn farmers are expected to be more open and receptive to seek and absorb 
and implement the technology of cultivation of maize, in particular to the use of production inputs that are more efficient in their farming activities so that the resulting production will be better and increased. For this reason also expected support from the Government in terms of supervision and monitoring directly to the distribution of the production facilities and infrastructure, for example the fertilizer and superior seeds, so the scarcity of fertilizer and superior seeds will be able to reduced or minimized.
Education institutions that locatedmin Sigi Sub District as well as West Dolo district, expected to maximize the participation of the agricultural extension workers in providing guidance and assist farmers in adopting technological innovations. The extension workers is expected to be able to provide information (technology transfer) to the farmers, especially on how to improve the production and exploit the production inputs more efficiently.

\section{REFERENCES}

Baswarsiati. 2005. Upaya BPTP Jawa Timur dalam Penyediaan Benih Sumber, Aspek Penerapan Teknologi dan Pola Kemitraan Penyediaan Benih Sumber Bawang Merah. Makalah Pertemuan Aprisiasi Penangkaran Benih Bawang Merah di Brebes, Juli 2005. BPTP Jawa Timur. Surabaya.

Fitriawati. A. 2009. Analisis Faktor-Faktor yang Mempengaruhi Produksi Jagung di Desa Bobo Kecamatan Palolo Kabupaten Donggala. Tesis (Tidak dipublikasikan) Pascasarjana Universitas Tadulako. Palu.

Gujarati, D.N. 1995. Basic Economtrics. McGraw-Hill International Edi-tions. Printed in Singapore. Third Edition.

Indraningsih. K.C, 2011. Pengaruh Penyuluhan Terhadap Keputusan Petani dalam Adopsi Inovasi Teknologi Usahatani Terpadu. Jurnal Agro Ekonomi. Pusat Sosial Ekonomi dan Kebijakan Pertanian. Bogor. Vol. 29. No.1 Mei. 2011: 1-24.

Khaerizal. H. 2008. Analisis Pendapatan dan Faktor-Faktor Produksi Usahatani Komoditi Jagung Hibrida dan Bersari Bebas (Lokal) (Kasus: Desa Saguling, Kecamatan Batujajar, Kabupaten Bandung, Provinsi Jawa Barat. Skripsi (Tidak dipublikasikan) Program Sarjana Ekstensi Manjemen Agribisnis. Institut Pertanian Bogor. Jawa Barat.

Mardikanto, T., 1993. Penyuluhan Pembangunan Pertanian. Sebelas Maret University Press. Surakarta.

Mudakir, B., 2011. Produktivitas Lahan dan Distribusi Pendapatan Berdasarkan Status Penguasaan Lahan pada Usahatani Padi (Kasus di Kabupaten Kendal Propinsi Jawah Tengah). J. Dinamika Ekonomi Pembangunan Vol. 1 No. 1. Juli 2011. Fakultas Ekonomika dan Bisnis Universitas Diponegoro Semarang.

Ola dan Andreas Sukamto. 2013. Pendapatan dan Fungsi Produksi Jagung (Studi Kasus pada Usahatani Jagung di Pedukuhan Sawah, Monggol, Saptosari, Gunungkidul). Jurnal. Universitas Atma Jaya Yogyakarta.

Rachman B, I. Wayan Rusastra dan Ketut Kariyasa., 2000. Sistem Pemasaran Benih dan Pupuk serta Pembiayaan Usahatani. Pusat Penelitian dan Pengembangan Sosial Ekonomi Pertanian. Bogor.

Rukmana, H. 2008. Usahatani Jagung. Kanisius. Jogyakarta.

Sahara. D, dan Idris, 2006. Efisiensi Produksi Sistem Usahatani Padi pada Lahan Sawah Irigasi Teknis. Balai Pengkajian Teknologi Pertanian (BPTP) Sulawesi Tenggara. Kendari. Online HTML. Diakses Mei 2014.

Suparyono dan Setyono. 1993. Padi. Jakarta: PT. Penebar Swadaya.

Sutopo, L., 2003. Teknologi Benih. Rajawali. Jakarta.

Tulus TH Tambunan, 2003. Perkembangan Sektor Pertanian di Indonesia. Ghalia. Jakarta. 